\title{
HYPOTHESIS
}

\section{Coprecipitating IgG asymmetric antibodies: a possible role for Fab glycosylation, and speculations on their formation and functions in disease}

\author{
Ricardo A. Margni \\ IDEHU-Instituto de Estudios de la Inmunidad Humoral (CONICET-UBA), Departamento de \\ Microbiologia, Inmunologia y Biotecnologia, Facultad de Farmacia y Bioquimica de la Universidad de \\ Buenos Aires, Argentina
}

IgG asymmetric antibodies are synthesized by the same cellular clones as the symmetric ones but appear in the immune response in different proportions. The evidence suggests that they are caused by asymmetric glycosylation on some IgG molecules in the Fab region. The cause of this is unknown but it could be speculated that there are cellular factors that induce glycosyl transferases or cause the molecule to be more accessible to glycosylation. The production of asymmetric antibodies can be modified by the physical status (soluble or particulate) of the antigen used as immunogen by the number and frequency of stimulation, and by physiological factors such as the ones secreted by the placenta and by lymphocytes that express progesterone receptors in response to hormone. An increase of these antibodies can be beneficial or harmful to the host, depending on the situation in which they act and the character of 'self' or 'non-self' of the antigens recognized.

Keywords: asymmetric antibody, blocking antibody, chronic infections, non-precipitating antibody, placental factors, pregnancy

\section{Introduction}

Changes in the quantity and quality of antibodies occur in the course of an immune response. Qualitative changes in IgG antibodies are very interesting, especially those observed in chronic microbial and parasitic infections, or when particulate anti-

Address for correspondence: Professor R. A. Margni. Facultad de Farmacia y Bioquimica de la Universidad de Buenos Aires, Junin $956,4^{\circ}$ piso, 1113-Buenos Aires, Argentina. Fax: $(+54)$ 19625341 . gens are repeatedly injected for a long period of time. It is well known for more than half a century that there is an optimal antigen dose (equivalence point) that precipitates all the antibody from a fluid $[1,2]$. If the antigen is added in small successive fractions, $10-15 \%$ of the total antibodies do not precipitate; nevertheless, they can be incorporated into the precipitates that are formed by the precipitating antibodies. These non-precipitating antibodies were named 'coprecipitating antibodies'. 


\section{What are coprecipitating antibodies?}

In 1970 we began the analysis of these antibodies [3]. They were found in all subclasses of $\operatorname{IgG}$ in different animal species [3-11]. They do not form insoluble complexes with antigen [3], they do not fix complement $[3,10,12]$, they are cytophilic to macrophages and macrophages were inactive for in vitro phagocytic activity [12]. When purified coprecipitating antibody was injected intravenously into a mouse it did not induce the clearance of a specific antigen [12].

Precipitating and coprecipitating antibodies interact with the same epitope $[5,8,13]$. Since coprecipitating antibodies can firmly combine with an antigen, they act in a competitive way when they are mixed with precipitating antibodies of the same specificity. In complement fixation, it was demonstrated that at a 1:5 coprecipitating:precipitating antibody ratio the effect is significant, and at a 4:5 ratio, complement fixing activity is practically abolished $[12,14]$. Competition was also demonstrated in the clearance of circulating antigen $[10,12,15]$. These results show that the biological activity of a serum sample depends upon its coprecipitating: precipitating antibody ratio.

Coprecipitating antibodies do not provoke an Arthus reaction and in heterologous passive cutaneous anaphylaxis (PCA) these antibodies appear to be less effective than precipitating ones [3]. The same was observed when the protective activity of precipitating and coprecipitating antibodies against toxins and bacteria were analysed $[9,10,15,16]$.

No antigenic differences were detected between precipitating and coprecipitating antibodies. Antisera prepared by immunization of rats with either precipitating or coprecipitating antibodies of the same IgG isotype, and isolated from the same serum sample, interacted identically with both precipitating and coprecipitating antibodies in immunodiffusion tests. Furthermore, these antisera could be completely absorbed with either precipitating or coprecipitating purified antibodies. In all the biochemical and immunochemical tests performed $[3,4]$ (electrophoresis, peptide and diagonal mapping (fingerprints), gel filtration, sedimentation molecular weight analysis, etc), precipitating and coprecipitating antibodies had identical structures [17, 18].

Precipitating and coprecipitating antibodies have two paratopes. Nevertheless, coprecipitating antibody behaves in an univalent manner. This was further demonstrated when equilibrium experiments (equilibrium dialysis, quenching of fluores- cence and radiobinding studies) were performed with monovalent haptens $[5,8]$. It was shown that coprecipitating antibody, or its $\mathrm{F}\left(\mathrm{ab}^{\prime}\right) 2$ fragment, had one paratope of high affinity, with a $K_{0}$ similar to that of the precipitating antibody, and a paratope with an affinity for the hapten about 100 times lower than the other combining site. When coprecipitating antibody interacted with a big ligand (antigen), equilibrium experiments showed that only one paratope recognised the antigen [13]. These results explain why this antibody is unable to form large antigen-antibody complexes and has unique biological behaviour.

\section{Evidence for involvement of carbohydrate}

We have demonstrated that the inability of the non-precipitating antibodies to precipitate antigen is a consequence of steric hindrance created in one of the combining sites by a carbohydrate moiety attached to the $\mathrm{Fd}$ fragment of the Fab region. This is of low affinity [19]. A mannose rich oligosaccharide is the predominant sugar that creates the functional asymmetry. In view of this we have proposed that these antibodies should be called 'IgG asymmetric antibodies' [13].

Oligosaccharide residues were detected on the $\mathrm{L}$ chain only on monoclonal IgG antibody [20] but not on polyclonal antibodies [19,21]. The failure to detect glycosylated $\mathrm{L}$ chains on polyclonal antibodies could be explained by the dilution of a few glycosylated $L$ chains in the pool of non-glycosylated $L$ chains.

After enzymatic treatment with endo- $\beta-N$ acetylglucosaminidase $H$, an enzyme that removes oligosaccharide attached to the Asn residue of the protein, an asymmetric antibody and its $F\left(a b^{\prime}\right) 2$ fragment behaved the same as a precipitating antibody [20]. These results indicate that the carbohydrate moiety participates in the generation of the functional univalence.

As the $F(a b) 2$ fragments of asymmetric antibodies bind to concanavalin A [19], these fragments can be purified from IgG asymmetric molecules by affinity chromatography with Con A-Sepharose. It was demonstrated that $10-15 \%$ of IgG molecules of non-immune sera of man are asymmetrically glycosylated [21]. Hybridomas synthesize both symmetric and asymmetric molecules in different proportions depending on the clone [20].

The physicochemical, immunochemical and bio- 
logical properties of IgG asymmetric antibodies have been reviewed by Margni and Binaghi [17].

Table 1 summarizes immunochemical and biological properties of symmetric and asymmetric antibodies.

\section{What are the functions of asymmetric antibodies?}

Considering the antigen blocking capacity of $\mathrm{IgG}$ asymmetric antibodies and their particular biological behaviour, the existence of these antibodies may be beneficial or harmful to the host, depending on the character of 'self' or 'non-self' antigens involved, and the particular situation in which they act. In chronic microbial and parasitic infections, an increase of IgG asymmetric antibodies was detected [14,22-26]. Possibly they could act by providing an escape mechanism for the invader, and potentiating the chronicity of the process. In rabbits and sheep, fortnightly injected with particular antigens for 1 year, the proportion of $\mathrm{IgG}$ asymmetric antibodies detected was $30-70 \%$, whilst with soluble antigens, this was only $10-15 \%$ $[7,27]$. This could explain the increase in these antibodies in chronic infections, where particulate antigens (bacteria or parasite) stimulate repeatedly for a long period of time.

Many of the self antigens generally associated with cells could act as particular immunogens. As a consequence, a great part of the 'non-immune' IgG asymmetric molecules of the host could be 'self specific' acting as autoprotective and regulating antibodies [28]. This is in line with the suggestion of Cohen and Cooke [29] that 'natural antibodies' could act by blocking self or selfmimicking epitopes and so prevent the initiation of a damaging autoimmune response. These univalent asymmetric antibodies would be ideal for an effective idiotype-anti-idiotype network proposed by Jerne [30]. As they could not cause aggregates which could trigger immune effector mechanisms, they would provide optimal interactions between idiotypes and paratopes [28].

In previous studies, we demonstrated that during pregnancy there is a considerable increase in total IgG asymmetric molecules (specific plus nonspecific), reaching $25-30 \%$ in sera and $35-60 \%$ when they were eluted from placenta with $4 \mathrm{M}$ $\mathrm{KCl}$ [31]. Antipaternal antigen activity, measured by IF and complement fixation using paternal lymphocytes as the target, is lower for IgG asymmetric molecules isolated from serum than from placenta. The concentration of antipaternal antibodies eluted from placenta was about three times higher in the asymmetric IgG fraction than in the symmetric one. Taking this fact into account, and the antigen blocking effect of asymmetric antibodies, this suggests that these antibodies participate in fetal protection.

Preferential synthesis of asymmetric antibodies in female Fischer rats immunized with Buffalo male rat particulate antigens (spleen cells) was demonstrated. When the Fischer rats were immunized before mating with the Buffalo rats, fetus and placenta weights, and offspring survival, were greater than in the control group, suggesting a beneficial effect of the antibodies in pregnancy [32]. This is in agreement with the results obtained when women who have recurrent spontaneous abortions are immunized with paternal cells, and

Table 1. Immunochemical and biological properties of symmetric and asymmetric antibodies

\begin{tabular}{|c|c|c|}
\hline Property & Symmetric & Asymmetric \\
\hline Molecular weight & $150-160 \mathrm{kDa}$ & $150-160 \mathrm{kDa}$ \\
\hline Immunoglobulin class & $\operatorname{IgG}$ & IgG \\
\hline Affinity & two paratopes of high affinity & $\begin{array}{l}\text { one paratope of high affinity; } \\
\text { one paratope of low affinity }\end{array}$ \\
\hline Glycosylation of one Fab & no & yes \\
\hline Precipitating activity & + & - \\
\hline Complement fixing capacity & + & - \\
\hline Neutralizing activity & high & low \\
\hline Clearance of antigen from the blood & + & - \\
\hline Binding to Con A & - & + \\
\hline \multicolumn{3}{|l|}{ Proportion in animals repeatedly injected with: } \\
\hline soluble antigen & $85-90 \%$ & $10-15 \%$ \\
\hline particulate antigen & $30-70 \%$ & $70-30 \%$ \\
\hline Presence in chronic bacterial and parasitic infections & low proportion & high proportion \\
\hline
\end{tabular}


no abortions [33] and larger children are observed [34].

Non-precipitating blocking antibodies have been demonstrated in tumours [35]. They can enhance or facilitate tumour growth [36]. IgG asymmetric antibodies may also be operating in allergy as they are implicated in the clinical improvement following specific antiallergen therapy. There is strong evidence that specific IgG blocking antibody is protective in allergy, and that the efficacy of immunotherapy is dependent on changing the balance between harmful IgE antibodies and protective blocking IgG antibodies [37]. Better results were obtained when polyethylene glycol-modified allergens were used instead of soluble allergens when given in repetitive injections [38]. This is in agreement with the preferential synthesis of $\mathrm{IgG}$ asymmetric blocking antibodies by rabbits and rats when polymerized-soluble antigen (bovine serum albumin) or particulate antigens (lymphocytes) are used as immunogens [27, 32].

The synthesis of suppressor factors of the cellular immune response by the placenta have been described [39]. Recently, we have demonstrated that when the supernatant of placental cultures is added to a hybridoma, it is able to increase the asymmetric:symmetric ratio of IgG molecules synthesized [40]. The same change was observed in virgin rats immunized with ovalbumin and intraperitoneally injected with the supernatant of placental cultures. In this case, a high increase of IgG asymmetric anti-ovalbumin molecules was detected (Gentile and Margni, submitted).

Lymphocytes in pregnancy may express specific progesterone binding sites. When pulsed with the hormone these lymphocytes produce a factor with immunological actions which include inhibition of natural killer mediated lysis, increase of cells with suppressor phenotype, and inhibition of proliferation in the mixed lymphocyte reaction [41, 42]. This factor has been shown to function in a similar way to the placental factors indicated above, i.e. increasing the proportion of IgG asymmetric molecules (manuscript in preparation).

\section{Speculations}

\section{Possible mechanisms for the induction of} asymmetric glycosylation

Immunoglobulin molecules result from the association of two half molecules each composed of one heavy $(\mathrm{H})$ chain and one light (L) chain (H2L2). H1L1 and H2L1 have also been detected in the cytoplasm. Analysis of $N$-linked oligosaccharides from serum IgG has shown that $2.8 \mathrm{~N}$-linked oligosaccharides are attached to each IgG molecule, 0.8 of which, on average, are located in the Fab fragment [43]. It has been proposed that the frequency and location of the glycosylation sequon Asn-X-Ser/Thr is responsible for this extra glycosylation [44]. In mouse, it has been demonstrated that $V_{H}$ genes contain glycosylation sequons, suggesting their participation in the generation of Fab glycosylation [45]. In Fab fragments of IgG monoclonal antibodies we have shown oligosaccharides with monosialylation and highmannose structures [46].

Further structural studies of the sugar chains of serum IgG [47] have revealed that these components give rise to extremely high microheterogeneity. Despite this microheterogeneity, the molar ratio for each of these oligosaccharides in $\mathrm{IgG}$ from the sera of healthy individuals is quite constant [48]. These results suggested that $B$ cells are equipped with particular sets and ratios of glycosyltransferases [49]. Nevertheless, under certain circumstances post-translational modification of a peptide by $N$-glycosylation could lead to an increase of a particular glycoform. Glycoforms from the same cell arise from the modification of a single polypeptide by the action of glycosyl transferase and glycosidases [50].

The above mechanisms possibly participate in the asymmetric glycosylation of IgG molecules, but what determines the modification? Taking into account the differences observed when soluble or particulate antigens are successively injected for a long period of time, it is possible that different presenting cells participate in antigen capture. Thus cells could synthesize different factors (cytokines) that act to inhibit or stimulate the activity of glycosyl transferases, and these change glycosylation and produce different glycoforms. If soluble and particular antigens are recognised by the same cell, then their capture by endocytosis (soluble antigen) or phagocytosis (particulate antigen) may activate different internal systems which induce modifications in the normal pattern of glycosylation. Of some relevance may be the reported post-translational modification of the activity of $\beta$-1,4-galactosyltransferase by phosphorylation mediated by a 588 protein kinase [51].

Changes in glycosylation could also occur through variations in the $\mathrm{H}$ chain peptide folding which cause the exposure of new glycosylation sequons. It is interesting to note that our results show variations in the proportion of symmetric and 
asymmetric IgG antibodies synthesized by hybridomas when $10^{-5} \mathrm{M}$ cysteine or $10^{-5} \mathrm{M} 2$-mercaptoethanol are incorporated into the culture medium. This could be due to variations in the $H$ chain folding caused by competition between cysteine or 2-mercaptoethanol sulphydryl group and the $\mathrm{H}$ chain sulphydryl groups for the enzyme involved in the intrachain disulphide bridges.

Another possibility is that the antibody presenting cell reacts in a different way when it recognises a particulate antigen, inducing the $B$ lymphocyte to synthesize a cytosolic chaperone component. There is some evidence suggesting that the folding of newly-translated precursor proteins in the cytosol are prevented by the presence of aminoterminal presequences $[52,53]$. This may enable precursor unfolded or incompletely folded $\mathrm{H}$ chain polypeptide to interact with cytosolic chaperone components, such as the ct-hsp 70 family. This interaction could delay precursors destined for transport to the membrane. Because of this they could encounter glycosyltransferases, in a looselyfolded conformation, facilitating glycosylation of normally non-functional sequons [54-56].

\section{Further functions for asymmetric antibodies}

If asymmetric antibodies protect in pregnancy, is it correct to vaccinate at this time? If $\mathrm{IgG}$ asymmetric antibodies block antigens and cannot trigger the biological reactions responsible for antigenic damage, is it correct to vaccinate in pregnancy and induce the transfer of a protective congenital humoral immunity to the fetus? In this period there is a preferential synthesis of IgG asymmetric antibodies by the mother. Are IgG asymmetric antibodies synthesized at the same proportion during the whole of the pregnancy? Studies are in progress in our laboratory on pregnant rats, rabbits and mares injected with tetanus toxoid or eggalbumin. These should indicate variations in the proportion of serum IgG asymmetric antibodies against both antigens during pregnancy. Preliminary results in rats have shown an increase of asymmetric molecules, especially in the first week and the beginning of the second week of the pregnancy.

Could factors that regulate the glycosylation of asymmetric antibodies be used for the treatment of recurrent abortions and autoimmune diseases? What are the factors involved in asymmetric glycosylation in pregnancy? Are they related to other regulatory factors such as cytokines, cellular growth factors or differentiation factors? When they are identified they may be useful for therapeutic use, especially in the prevention and treatment of recurrent spontaneous abortion, where in many cases, an increase of biologically active precipitating anti-paternal antibodies has been demonstrated. Also, they will be useful in autoimmune diseases, where the preferential synthesis of specific blocking antibodies could protect self antigens.

Do factors that induce asymmetric antibodies cause tumour cell proliferation? Mammary carcinoma have been described that are related to pregnancy. In this situation is the immune response influenced by placental factors inducing a predominance of asymmetric IgG molecules? The presence of these tumours could be connected with this phenomenon. Different mechanisms could stimulate resting tumour cells, and exposed neoantigens could induce a humoral immune response with predominance of $\operatorname{IgG}$ asymmetric antibodies. These would be unable to carry out surveillance, but with blocking activity they would facilitate tumour cell proliferation. A similar speculation can be made for factors liberated by lymphocytes from pregnant women. These express nuclear progesterone receptors, when they interact with the hormone. This mechanism could be operating in hormone treatments with progesterone and derivatives. The presence of mammary carcinoma in menopausal women treated with progesterone has been reported.

Could the beneficial effects of pre-operative blood transfusions in kidney transplants be due to asymmetric antibodies? Progesterone receptors are induced in vitro by mitogenic or alloantigenic stimulation of non-pregnancy lymphocytes [57]. In vivo allogeneic stimulation has similar effects, as shown by the high numbers of progesterone receptor positive cells in peripheral blood of liver transplanted patients who receive blood transfusion [58]. If these conditions produce a predominance of IgG asymmetric blocking antibodies, this could explain the beneficial effect for kidney transplantation of previously transfusing patients with small amounts of blood from the donor. This allogeneic stimulation could induce a beneficial immune response against the transplanted kidney antigens. The specific IgG asymmetric antibodies synthesized could block and protect against the foreign antigens. 


\section{Acknowledgements}

The research activities leading to this work were supported by grants from CONICET (Consejo Nacional de Investigaciones Cientificas y Tecnicas) Argentina and University of Buenos Aires.

\section{References}

1. Heidelberger M, Kendall FE. A quantitative theory of the precipitin reaction. III-The reaction between crystalline egg albumin and its homologous antibody. J Exp Med 1935: 62; 697-720.

2. Heidelberger M, Treffers HP, Meyer M. A quantitative theory of the precipitin reaction. VII-The egg albumin-antibody reaction in sera from the rabbit and horse. J Exp Med 1940: 71; 271-82.

3. Margni RA, Binaghi RA. Purification and properties of non-precipitating rabbit antibodies. Immunology 1972: 22; 557-63.

4. Margni RA, Hajos SE. Biological and phisicochemical properties of purified anti-DNP guinea-pig nonprecipitating antibodies. Immunology 1973: 24; 435-43.

5. Cordal ME, Margni RA. Isolation, purification and biological properties of horse precipitating and nonprecipitating antibodies. Immunochemistry 1974: 11; 765-70.

6. Margni RA, Paz CB, Cordal ME. Immunochemical behaviour of sheep non-precipitating antibodies isolated by immunoadsorption. Immunochemistry 1976: 13; 209-14.

7. Margni RA, Castrelos OD, Paz CB. The sheep immune response. Variation of anti-hapten and anticarrier antibodies in the $\gamma 1$ and $\gamma 2$ immunoglobulin fractions. Immunology 1973: 24; 781-9.

8. Margni RA, Cordal ME, Leoni J, et al. Nonprecipitating antibodies isolated by immunoadsorption. Immunochemistry 1977: 14; 299-303.

9. Parma AE, Santisteban G, Margni RA. Analysis and in vivo assays of cattle agglutinating and nonagglutinating antibodies. Vet Microbiol 1984: 9; 391-8.

10. Perdigón G, Margni RA, Gentile T, Abátangelo C. Human anti-tetanus toxin precipitating and coprecipitating antibodies. Immunology 1982: 45; 183-90.

11. Malan Borel I, Gentile T, Angelucci J, Margni RA, Binaghi RA. Asymmetric Fab glycosylation in guinea-pig IgG1 and IgG2. Immunology 1990: 70; 281-3.

12. Margni RA, Perdigón $\mathrm{G}$, Abatángelo $\mathrm{C}$, Gentile $\mathrm{T}$, Binaghi RA. Immunobiological behaviour of rabbit precipitating and non-precipitating (coprecipitating) antibodies. Immunology 1980: 41; 681-6.

13. Ronco J, Sciutto E, Leoni J, Margni RA, Binaghi RA. Interaction of purified precipitating and nonprecipitating (coprecipitating) antibodies with hapten and with haptenated protein. Evidence of an asymmetrical antibody molecule. Immunology 1984: 52; 449-56.

14. Carbonetto $\mathrm{CH}$, Malchiodi EL, Margni RA. IgG antibody type in sera from patients with chronic Chagas' disease. Immunologia (Barcelona) 1986: 5; 18-23.

15. Margni RA, Parma AE, Cerone S, Erpelding A, Perdigón G. Agglutinating and non-agglutinating antibodies in rabbits inoculated with a particulate antigen (Salmonella typhimurium). Immunology 1983: 48; 351-9.

16. Miranda S, Malan Borel I, Dokmetjian J, Margni RA, Binaghi RA. Asymmetric non-precipitating antibodies in commercial hyperimmune gammaglobulin for therapeutic use. Immunology 1992: 75; 707-9.

17. Margni RA, Binaghi RA. Non-precipitating asymmetric antibodies. Ann Rev Immunol 1988: 6; 535-54.

18. Ronco J, Sciutto E, Leoni J, Margni RA. Structural studies of sheep IgG1 precipitating and coprecipitating antibodies. Vet Immunol Immunopathol 1984: 5; 369-76.

19. Labeta M, Margni RA, Leoni J, Binaghi RA. Structure of asymmetric non-precipitating antibody: presence of a carbohydrate residue in only one Fab region of the molecule. Immunology 1986: 57; 311-7.

20. Morelli L, Leoni J, Fossati CA, Margni RA. Symmetric and asymmetric IgG antibodies are synthesized by the same cellular clone. Mol Immunol 1989: 26; 789-92.

21. Malan Borel I, Gentile T, Angelucci J, Margni RA, Binaghi RA. Asymmetrically glycosylated IgG isolated from non-immune human sera. Biochim Biophys Acta 1989: 990; 162-4.

22. Forget A, Borduas AG. An immunobiological enhancement phenomenon in experimental brucella infection of the chick. Int Archs Allergy Appl Immunol 1977: 53; 190-4.

23. McCutchan D, Katzenstein D, Norquist D, et al. Role of blocking antibody in disseminated gonococcal infection. I Immunol 1978: 121; 1884-8.

24. Hajos SE, Carbonetto $\mathrm{CH}$, Margni RA, Esteva M, Segura E. Purification and biological properties of anti-Trypanosoma cruzi antibodies isolated from patients with chronic Chagas' disease. Immunol Lett 1982: 4; 199-203.

25. Grzych JM, Capron M, Dissous C, Capron A. Blocking activity of rat monoclonal antibodies in experimental schistosomiasis. J Immunol 1984: 133; 998-1004.

26. Capron A, Dessaint P. Effector and regulatory mechanisms in immunity to schistosomes. Ann Rev Immunol 1985: 3; 455-476.

27. Margni RA, Perdigón G, Gentile T, Abatángelo C, Dokmetjian J. IgG precipitating and coprecipitating antibodies in rabbits repeatedly injected with soluble and particulate antigens. Vet Immunol Immunopathol 1986: 13; 51-61. 
28. Margni RA. Are the non-precipitating asymmetric antibodies autoprotective and regulatory antibodies? One opinion. Res Immunol (Inst Pasteur) 1989: 140; 725-9.

29. Cohen IR, Cooke A. Natural autoantibodies might prevent autoimmune disease. Immunol Today 1986: 7; 363-4.

30. Jerne NK. Toward a network theory of the immune system. Ann Immunol (Inst Pasteur) 1974: 125C; 373-89.

31. Malan Borel I, Gentile T, Angelucci J, et al. IgG asymmetric molecules with antipaternal activity isolated from sera and placenta of pregnant human. J Reprod Immunol 1991: 20; 129-40.

32. Gentile T, Malan Borel I, Angelucci J, Miranda S, Margni RA. Preferential synthesis of asymmetric antibodies in rats immunized with paternal particulate antigens. Effect on pregnancy. $J$ Reprod Immunol 1992: 22; 173-83.

33. Mowbray JF, Underwood JL. Effect of paternal lymphocyte immunization on birthweight and pregnancy outcome. In: Chaouat $\mathrm{G}$, Mowbray $\mathrm{J}$, eds. Cellular and Molecular Biology of the Materno-Fetal Relationship. Paris: John Libbey Eurotext, 1991; 295-302.

34. Wegmann TG. Paternal T cells promote placental growth and prevent spontaneous abortion. Immunol Lett. 1988: 17; 297-302.

35. Hajos SE, Alvarez E, Pierángeli S, Pasqualini CD, Margni RA. Antibodies against a tumor associated antigen in an AKR lymphoma conditioned to grow in a BALB/c mice. Vet Immunol Immunopathol 1984: 7; 53-63.

36. Voisin GA. Immunobiological intervention of the placenta in maternal immunological tolerance to the foetus. In: Sojima SI, Billington WD, eds. Reproduction Immunology. Amsterdam: Elsevier, 1983; 121.

37. Ewan PW. Allergen immunotherapy. Curr Opin Immunol. 1988/89: 1; 672-8.

38. Muller U, Rabson AB, Bischof $\mathrm{M}$, et al. A doubleblind study comparing monomethoxy polyethylene glycol-modified honeybee venon and unmodified honeybee venon for immunotherapy. 1-Clinical results. J Allergy Clin Immunol 1987: 80; 252-61.

39. Chaouat G, Kolb JP. Immunoactive products of placenta. IV-Impairment by placental cells and their products of CTL function at effector stage. $J$ Immunol 1985: 135; 215-21.

40. Margni RA, Malan Borel I, Kapovic M, et al. The proportion of symmetric and asymmetric IgG antibody molecules synthesized by a cellular clone (hybridoma) can be regulated by placental culture supernatants. Cell Immunol 1992: 142; 287-95.

41. Szekeres-Bartho J, Kilar F, Falkay G, et al. Progesterone-treated lymphocytes of healthy pregnant women release a factor inhibiting cytotoxicity and prostaglandin synthesis. Am J Reprod Immunol Microbiol 1985: 9; 15-18.

42. Szekeres-Bartho J, Varga P, Kinsky R, Kapovic M, Chaouat G. Progesterone dependent immuno- modulation during pregnancy. In: Chaouat G, Mowbray J, eds. Cellular and Molecular Biology of the Materno-Fetal Relationship Paris: John Libbey Eurotext, 1991: 212; 309-15.

43. Parekh RB, Dwek RA, Sutton DJ, et al. Association of rheumatoid arthritis and primary osteoarthritis with changes in the glycosylation pattern of total serum IgG. Nature 1985: 316; 452-7.

44. Rudd MP, Leatherbarrow RJ, Rademacher TW, Dwek RA. Diversification of the IgG molecule by oligosaccharides. Molecular Immunology 1991: 28; 1369-78.

45. Kimura H, Buescher ES, Ball ED, Marcus DM. Restricted usage of $\mathrm{VH}$ and VK genes by murine monoclonal antibodies against 3-fucosyllactosamine. Eur J Immunol 1989: 19; 1741-6.

46. Morelli L, Plotkin L, Leoni J, Fossati CA, Margni RA. Analysis of oligosaccharides involved in the asymmetrical glycosylation of IgG monoclonal antibodies. Mol Immunol 1993: 30; 695-700.

47. Takasaki S, Mizuochi T, Kobata A. Hydrazinolysis of asparagine-linked sugar chains to produce free oligosaccharide. Methods Enzymol 1982: 83; 263-8.

48. Mizuochi T, Taniguichi T, Schimizu A, Kobata A. Structural and numerical variations of the carbohydrate moiety of immunoglobulin G. $J$ Immunol 1989: 129; 2016-20.

49. Furukawa K, Kobata $\mathrm{A}$. IgG galactosylation. Its biological significance and pathology. Mol Immunol 1991: 28; 1333-40.

50. Parekh R, Isenberg D, Rook G, et al. A comparative analysis of disease-associated changes in the galactosylation of serum IgG. I Autoimmun 1991: 2; 101-14.

51. Bunnell BA, Adams DE, Kidd VJ. Transient expression of a $\mathrm{p} 58$ protein kinase cDNA enhances mammalian glycosyltransferases activity. Biochem Biophys Res Commun 1990: 171; 196-203.

52. Hartl FU. Heat shock proteins in protein folding and membrane translocation. Seminars in Immuno$\log y, 1991: 3 ;$ 5-16.

53. Rothman JE. Polypeptide chain binding proteins: catalysis of protein folding and related processes in cells. Cell 1989: 59; 591-601.

54. Randall LL, Hardy SJS. Correlation of competence for export with lack of tertiary structure of the mature species: a study in vivo of maltose-binding protein of E. coli. Cell 1986: 46; 921-8.

55. Randall LL, Hardy SJS. Unity in function in the absence of concensus in sequence: role of leader peptides in export. Science 1989: 243; 1156-9.

56. Kaufmann SHE. Heat shock proteins and the immune response. Immunol Today 1990: 11; 129-36.

57. Szekeres-Bartho J, Chaouat G. A lymphocytederived progesterone inducing blocking factor corrects resorption in a murine abortion system. $A m J$ Reprod Immunol 1990: 23; 26-28.

58. Szekeres-Bartho J, Weill BJ, Mike G, Houssin D, Chaouat G. Progesterone receptors in lymphocytes of liver transplanted and transfused patients. Immunol Lett 1989: 22; 259-62. 
Editors note-Many of the ideas proposed in this article are very speculative, but it was thought appropriate to publish it in order to stimulate further discussion of the subject. It is an interesting role for Fab glycosylation that is proposed by Professor Margni. The ideas discussed are not necessarily those held by the Editorial Board or the reviewers, who felt that the evidence for many of the deductions made was very limited. It was also emphasized by the reviewers that the author's case would be substantially improved if more corroborative evidence was available from other groups. The Editors would welcome any comments on the subject for publication in future issues of the journal.

(Received 16 December 1993; accepted in revised form 5 February 1994) 